Article

\title{
Applying Effective Sensory Marketing to Sustainable Coffee Shop Business Management
}

\author{
Ha-Won Jang $(1)$ and Soo-Bum Lee * \\ College of Hotel and Tourism Management, Kyung Hee University, Seoul 02447, Korea; janghawon@khu.ac.kr \\ * Correspondence: lesoobum@khu.ac.kr
}

Received: 24 October 2019; Accepted: 14 November 2019; Published: 15 November 2019

check for updates

\begin{abstract}
This study focused on sensory marketing that appeals to the five senses of coffee shop customers ("sight," "smell," "sound," "taste," and "touch") to provide a sustainable growth model for the saturated coffee shop market. The study identified the relationships among coffee shops' sensory marketing factors, the "PAD" emotions (pleasure, arousal, and dominance), flow, and behavioral intentions. It employed an online survey of coffee shop customers aged 20 years and older. A total of 608 surveys were used for the final analysis. The results showed that there are statistically meaningful relationships between "sight" and dominance, "sound" and arousal, "taste" and dominance, "taste" and arousal, "touch" and dominance, and "touch" and arousal. In addition, it was confirmed that there are significant relationships among the PAD emotions; pleasure also has positive effects on flow and behavioral intentions. Finally, this study found significant moderating effects of hedonic and utilitarian usage motivations on the hypothesized relationships. Based on our findings, several important academic and business implications are provided, which can contribute to the sustainability of coffee shops.
\end{abstract}

Keywords: five senses; sensory marketing; coffee shops; PAD emotions; flow; behavioral intentions; coffee shops' usage motivations

\section{Introduction}

Coffee is one of the most popular beverages in the world, and the coffee industry is considered an important and high value-added business [1]. However, the coffee shop market is highly saturated; businesses are experiencing difficulties owing to a rapid increase in the number of coffee shops, not only those of globally popular franchises but also shops belonging to independent brands [2]. For example, in the United Kingdom (U.K.), there were approximately 10,000 coffee shops in 2007, but that number more than doubled after 10 years to 22,000. Owing to this saturated market, Costa, one of the major coffee shop franchises in the U.K., announced that it does not plan to open a new shop for the next five years; other franchises are making similar decisions [3]. Competition among coffee shops has reached a peak in the United States as well; analysis indicates that the market has reached a saturation point [4]. This situation has been also observed in Asian countries including South Korea. As over 1000 coffee shops in South Korea closed in 2018, its import of coffee bean has declined for the first time since 2012. This implies that South Korea's coffee shop market has reached the saturation point as well [5]. Companies all over the world and across industries, including the coffee shop industry, are placed in a competitive structure where there is an endless number of new market entries. Therefore, differentiated strategies are required to survive in their respective industries [6]. Over the past few years, such challenges and the need for solutions have led to increasing interest in this developing reality and in the sustainability of business from a long-term perspective. Accordingly, there are numerous studies addressing how to achieve sustainable business performance [7]. The food service industry, which includes the coffee shop business, has also implemented effective sustainable management strategies [8]. 
Large coffee shop franchises, in particular, have established various operational strategies, and there is a need for new marketing strategies for sustainable growth [6].

Accordingly, scholars have conducted studies on various marketing strategies for coffee shops. They have focused on marketing strategies based on customer relationships [9], brand image improvement [10,11], and corporate social responsibility [12]. These studies were based on the traditional marketing viewpoint that consumers select coffee shops using rational decisions.

Today's consumers expect a greater variety of purchasing and consumption experiences [13]. Kim and Jung (2018) stated that modern consumers focus on unique and sensory experiences [14]. To support this argument, the focus of recent research has been on the importance of sensory marketing utilizing human senses [14].

Hulten (2015) argued that sensory marketing that stimulates the five senses can positively affect an individual's consumption activities [15]. Sensory marketing induces positive emotions that ultimately lead to behavioral reactions such as purchases or re-visits [16]. Kuczamer-Kłopotowska (2017) agreed that sensory marketing influences consumer purchasing decision-making [13]. Thus, sensory marketing improves brand and product awareness and leads to more positive consumption behavior by helping build consumer trust. Sensory marketing has been applied to various contexts such as package design [17], clothing stores [18,19], and fast food brand design [20,21]. A major part of the relevant literature has examined how a particular location or environment significantly stimulates individuals' senses and further impacts their behavioral intentions. However, few studies have applied sensory marketing to the context of coffee shops [22]. Hence, this study investigates sensory marketing strategies by encompassing all five human senses based on the various selection attributes of coffee shops.

Most studies address the effects of marketing on only two types of customers' emotions, pleasure and arousal. Given the increasing number of customers who visit coffee shops to study or conduct business, the feeling of personal ownership of, or connection to, the coffee shop that the customer chooses, should be addressed in addition to the consumer emotions of arousal and pleasure [23]. Therefore, this study captured the feeling of customer control, or ownership, regarding the space occupied, which represents dominance. A comprehensive model in this study was developed to investigate how coffee shop sensory marketing influences three emotions (pleasure, arousal, dominance; PAD) [24]. In addition, this study sought to verify two conclusions: that coffee shops' sensory marketing affects customer emotions, and further, that these emotions can lead to a flow derived from their pleasurable emotions and positive behavioral intentions.

Previous studies have identified that the usage motivations of coffee shops are divided into emotional motivations (i.e., drinking coffee, taking a break, hanging out with friends) and utilitarian motivations (i.e., studying, taking care of business, meeting others) [25]. Therefore, this study aims to verify the expectation that customers' different motivations for usage produce significant differences in the relationships among coffee shop sensory marketing, PAD emotions, flow, and behavioral intentions.

The goals of this study were to:

1. Identify the relationships between the five sensory marketing factors and coffee shop customers' PAD emotions;

2. Identify the relationships among coffee shop customers' PAD emotions;

3. Identify the effects of coffee shop customers' pleasure on their flow and behavioral intentions;

4. Verify significant differences among the relationships previously mentioned, according to coffee shop customer usage motivations (emotional vs. utilitarian).

\section{Research Background}

\subsection{Sensory Marketing Using Five Senses}

Sensory marketing, first suggested by Schmitt (1999), is a marketing strategy that stimulates consumer emotions instead of their rational judgment by appealing to the five human senses- "sight," "smell," "sound," "taste," and "touch" [26]. Later, Krishna (2012) defined sensory marketing as a 
marketing strategy that can not only affect consumers' five senses but can also consecutively affect their emotions, perceptions, judgment, and behavior [16]. Erdil (2015) explained the application mechanism of sensory marketing: it creates stimulation based on external environmental factors that can appeal to consumer senses [27]. These external environmental factors affect not only consumer emotions but also product or brand evaluations; therefore, these factors can ultimately affect customer purchase intentions and behavior [27].

According to Lindstrom (2006), external environmental stimuli affect all five human senses [28]. Humans are most affected by sight; the first impression conveyed through sight assists consumers in forming product and brand image [29]. "Sight" is the most effective sense for delivering sensory marketing messages to customers [30]. As smell is connected to breathing, it is the one sense that cannot be ignored [28,31]. "Smell" most directly and most quickly affects memory. Sound varies according to pitch, tempo, and intonation [16]. "Sound" has a long-term effect on the memory, and a vast amount of information is absorbed through sound [32]. "Taste" differentiates among sweet, salty, sour, bitter, and umami (savory) [33]. When humans consume food, the five senses operate in harmony [16], as food is not only related to taste, but also to smell, texture, appearance, and the sound of chewing [16]. Lastly, "touch" is a sensory factor felt by the skin. As touch occurs when a person comes into contact with something or someone, it leads to a rapport between the two, changing human emotions and considerably affecting communication [32].

Although sensory marketing can affect all five human senses, few prior studies consider all five sensory factors. For example, Wade Clarke et al. (2012) found the sensory marketing factors of "sight" and "smell" to have a significant impact on consumer shopping experiences in the fashion industry [18]. The literature adopts four of the five sensory marketing factors ("sight," "smell," "sound," and "touch"). Helmefalk and Hultén (2017) demonstrated the significant effects of these four sensory factors on retail customers' emotions [34]. In order to fill this gap in the existing literature, this study includes all five sensory factors applied to the context of coffee shop sensory marketing.

Sensory marketing is considered an important marketing strategy because it allows consumers to differentiate a particular product or brand in various decision-making situations related to consumption activities [17]. Considering the importance of this role, past studies have also applied sensory marketing to the food service industry. For example, Iqbal (2016) demonstrated that sensory marketing positively affects brand differentiation and brand loyalty [35]. Randhir et al. (2016) determined that playing music inside stores provides a sense of comfort for customers. They also discovered that smell produces a sense of arousal in customers at one fast-food company, Kentucky Fried Chicken (KFC) [36]. Moreira et al. (2017) found that sensory stimuli in pizza restaurants have positive effects on both brand experience and brand assets [37]. Several studies have identified the significant relationship between sensory marketing factors and a complex variety of human emotions $[24,38]$. Thus, this study expected to find significant effects of the five sensory marketing factors on coffee shop customers' various emotions, focusing on "pleasure," "arousal," and "dominance."

\subsection{Consumers' Pleasure-Arousal-Dominance Emotions: PAD}

Over the past decades, various studies highlighted the importance of a better understanding of how customer emotions influence their consumption behavior. In doing so, Mehrabian and Russell (1974) proposed the PAD model that explains human feelings using pleasure-arousal-dominance (PAD); this model is one of the most commonly used in the relevant literature [24]. Pleasure is enjoyment, happiness, or satisfaction; arousal is a feeling of excitement from an external stimulus; dominance is the feeling of control from oneself over a given situation [39]. The PAD model is useful for evaluating the effects of external environmental stimuli on the three emotions. PAD emotions are considered relevant to studies on environmental stimuli and consumer emotions [40]. Therefore, this study aims to provide a theoretical foundation in terms of coffee shop sensory marketing using the PAD emotions. 


\subsection{Consumers' Experiences: Flow}

Miller (1973) defined flow as the immersion in, and concentrated focus on a particular task [41]. Csikszentmihalyi and Csikszentmihalyi (1975) defined flow as the mental and physical commitment that occurs when people are completely immersed in an activity; they considered it a natural behavior that occurs when people identify themselves as one with the activity [42]. Gao and Bai (2014) stated that when people reach the state of flow, they are completely immersed in a particular situation and wish to continue with the activity [43]. Based on these definitions, prior studies have analyzed the major environmental factors that can lead customers to a state of flow. For example, Reid (2004) stated in a paper on virtual reality that user pleasure significantly affects flow [44]. Mun and Lee (2008) concluded that customer pleasure is a significant factor of flow within the context of social networking services (SNSs) [45]. They also stated that customer flow leads to extremely positive behavior in a consumption situation [43]. This finding was supported by an early study by Hoffman and Novak (1996), asserting that those who have experienced flow while shopping are likely to feel higher satisfaction and loyalty than those who have not had that experience [46]. Koufaris (2002), who verified this argument, also concluded that consumers who have experienced flow in a consumption situation are more likely to have impulse-buying behaviors [47]. Ko et al. (2014) stated that flow can improve users' awareness of a particular fashion brand [48]. Likewise, numerous studies have confirmed flow to have a positive effect on satisfaction, loyalty, and purchase intentions. This discussion led this study to expect that such relationships between pleasure and flow exist in the context of coffee shop sensory marketing.

\subsection{Development of Research Hypotheses}

The study set up hypotheses to identify the relationships among coffee shops' five sensory marketing factors, the PAD emotions of customers, flow, and behavioral intentions based on the discussions above. Furthermore, hypotheses were proposed regarding the possible differences among the relationships according to coffee shop usage motivation types (hedonic vs. utilitarian) (see Figure 1).

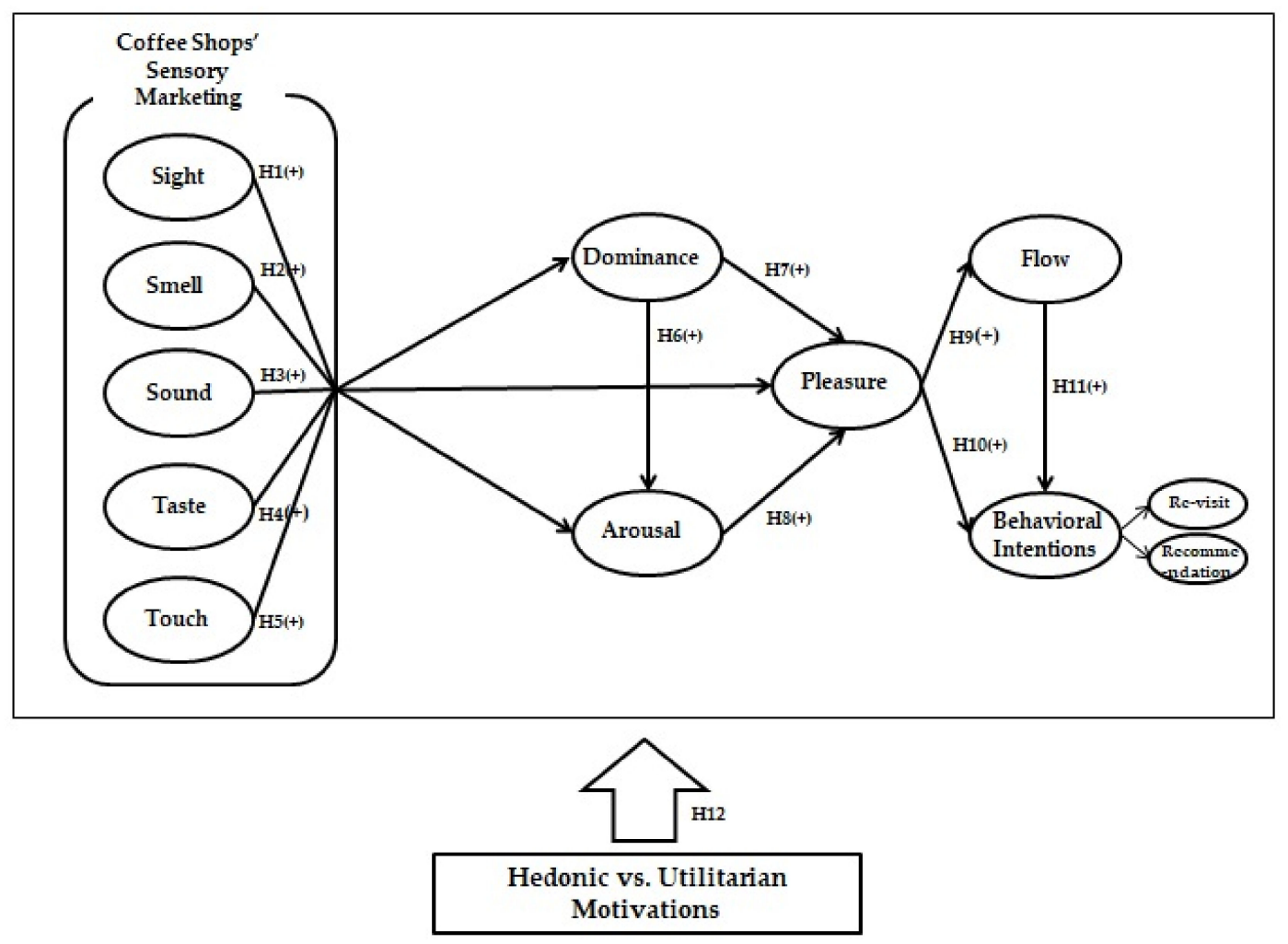

Figure 1. Research conceptual model. 


\subsubsection{Effects of Coffee Shops' Sensory Marketing on PAD Emotions}

A sensory marketing paper by Brengman (2002) focusing on "sight" stated that store color increases pleasure and arousal in customers [49]. Ryu and Jang (2007) identified visual factors such as the lighting and layout of restaurants that significantly affect customer dining pleasure [50]. Based on these studies, it can be assumed that "sight" will significantly affect customer emotions.

Krishna et al. (2013) argued that the innate "smell" of a particular location is a factor that has a strong effect on the people who use that location [51]. Studies that support this argument also determined that the sensory marketing factor of smell in restaurants has positive effects on emotions such as pleasure and arousal [50]. Therefore, it can be said that the sensory marketing factor of "smell" can significantly affect coffee shop customers' PAD emotions.

Ryu and Jang (2007) stated that "sound," such as music in a restaurant, increases both customer pleasure and arousal [50]. Jung (2015) stated that restaurant sounds have a positive effect on customers' feelings [52]. "Sound" in this study was expected to be another important sensory marketing factor that positively affects the PAD emotions of coffee shop customers.

Although there have been limited studies on the effects of "taste" on customer emotions, there have been a few that have verified this relationship. For example, Kang and Kim (2016) showed that taste associated with Japanese restaurants increases the feelings of pleasure and dominance [53]. Im (2017) verified a positive effect of the taste associated with dessert cafés on the feeling of dominance [54]. Based on these discussions, "taste" was likely to affect PAD emotions positively in this study's analysis of sensory marketing for coffee shops.

Hultén et al. (2009) stated that "touch" has a strong effect on human emotions [32]. Kim and Noh (2018) supported this argument with their study on the casino servicescape by verifying that "touch" factors, such as physical comfort, positively affect customers' feelings [55]. Therefore, for this study, it was purported that "touch" can be an important sensory marketing factor to have a positive effect on the PAD emotions of coffee shop consumers.

Based on these assumptions, to verify the significant effects of the five sensory marketing factors on customers' PAD emotions in the coffee shop context, the following five hypotheses were proposed:

Hypothesis 1: The sensory marketing factor of "sight" will have a positive effect on coffee shop customers' PAD emotions (H1a. Dominance; H1b. Pleasure; H1c. Arousal).

Hypothesis 2: The sensory marketing factor of "smell" will have a positive effect on coffee shop customers' PAD emotions (H2a. Dominance; H2b. Pleasure; H2c. Arousal).

Hypothesis 3: The sensory marketing factor of "sound" will have a positive effect on coffee shop customers' PAD emotions (H3a. Dominance; H3b. Pleasure; H3c. Arousal).

Hypothesis 4: The sensory marketing factor of "taste" will have a positive effect on coffee shop customers' PAD emotions (H4a. Dominance; H4b. Pleasure; H4c. Arousal).

Hypothesis 5: The sensory marketing factor of "touch" will have a positive effect on coffee shop customers' PAD emotions (H5a. Dominance; H5b. Pleasure; H5c. Arousal).

\subsubsection{Relationships between PAD Emotions}

Prior studies on PAD emotions have suggested that human emotions are complexly and intricately related to one another and that each emotion does not act on its own but can only be understood and explained based on interrelationships. For example, Babin and Darden (1995) and Ward and Barnes (2001) concluded that the dominance emotion experienced by a consumer significantly and positively affects the consumer's feelings of pleasure and arousal in the retail environment [56,57]. 
Kuppens (2008) and Hanzaee and Khanzadeh (2011) verified the relationship between pleasure and arousal $[58,59]$. Based on the results of these prior studies, it was expected that the results of this study would also show the relationships among the PAD emotions of coffee shop customers. Therefore, the following hypotheses were proposed:

Hypothesis 6: Coffee shop customer emotions of dominance will have a positive effect on arousal.

Hypothesis 7: Coffee shop customer emotions of dominance will have a positive effect on pleasure.

Hypothesis 8: Coffee shop customer emotions of arousal will have a positive effect on pleasure.

\subsubsection{Effects of Pleasure on Flow and Behavioral Intentions}

An early study by Clarke and Haworth (1994) found that pleasure significantly affects flow [60]. Csikszentmihalyi et al. (2014) studied the intrinsic rewards of people who participate in sports, art, and dance, and identified the strong relationship between pleasure and flow [61]. Kulviwat et al. (2016) asserted that customer pleasure increases flow in their study on shopping behavior [62].

Ryu and Jang (2008) and Tantanatewin and Inkarojrit (2018) concluded that consumer pleasure has a positive effect on consumers' behavioral intentions [63,64]. Ali (2016) and Liu et al. (2016) discovered that customer flow in an online environment has a positive effect on behavioral intentions $[65,66]$. Based on these findings, it was expected that coffee shop customers' pleasure has a positive effect on both flow and behavioral intentions. Therefore, the following additional hypotheses were proposed:

Hypothesis 9: Coffee shop customers' pleasure will have a positive effect on flow.

Hypothesis 10: Coffee shop customers' pleasure will have a positive effect on behavioral intention.

Hypothesis 11: Coffee shop customers' flow will have a positive effect on behavioral intention.

\subsubsection{Moderating Effects of Coffee Shop Usage Motivations (Hedonic vs. Utilitarian)}

Lunardo and Mbengue (2009) categorized usage motivations in shopping behavior as hedonic motivation and utilitarian motivation, and then identified different shopping behavior according to these motivations [67]. Jin, Lee, and Huffman (2012) showed that there is a significant difference in usage experience and brand image awareness, depending on usage motivations in their study of usage experiences at restaurant customer experiences [68].

Doucé and Janssens (2013) identified the moderating effect of customer usage motivation on the relationship between the sensory marketing factor of "smell" and emotions [19]. It has been shown that the unique smell of stores leads to greater pleasure for consumers with hedonic shopping motivation than it does for consumers with utilitarian shopping motivation [19]. Focused on the attractiveness of shopping centers, Margarita, Rialp, and González (2017) analyzed the moderating effects of usage motivation (hedonic and utilitarian) and studied the relationship between attractiveness and customer satisfaction [69]. Their results showed that customers with hedonic shopping motivations felt greater pleasure from the attractiveness of shopping centers compared to customers with utilitarian shopping motivations [69]. Hyun and Kang (2014) categorized usage motivations into utilitarian and hedonic motivations in their study of luxury restaurants. They analyzed the moderating effect on the relationship between physical environmental factors and customer emotions. Results showed that consumers with recreational motivations felt greater pleasure from arousal compared to those with task-oriented motivations [70]. Consistent with these two types of usage motivation, the following hypothesis was proposed: 
Hypothesis 12: Coffee shop usage motivations (hedonic and utilitarian) will have moderating effects on the relationships among the five sensory marketing factors, PAD emotions, flow, and behavioral intentions.

\section{Methods}

\subsection{Data Collection and Sampling}

This study chose samples from the following six brands of coffee shop franchises in Korea: Starbucks, Coffee Bean, Pascucci, Twosome Place, Angel-in-us, and Hollys. The subjects of this study were consumers aged 18 and older who had been customers of at least one franchise within the past three months. The choice of coffee shop franchises was based on brand awareness, shop size, coffee prices, and the focus on sensory marketing. Based on the results of the Korean Big Data Institute analyzing consumer coffee shop brand awareness, we selected six top brands for our study. There are 1262 Starbucks, 296 Coffee Bean, 408 Pascucci, 1001 Twosome Place, 554 Angel-in-us, and 405 Hollys outlets in South Korea. The average coffee price of all six brands ranges from $\$ 3.5$ to $\$ 5.8$. In addition, theses six franchises have been commonly recognized as places where customers can experience the five factors of sensory marketing within the premises of the coffee shops. Furthermore, all six brands focus on sensory marketing by creating a space filled with their own philosophies and stories, and offering a variety of coffee, baking fragrances, background music, elaborate menus, and comfortable furniture. The data were collected through an online survey company for approximately one week, between 2 July and 8 July 2019. Of the 635 collected surveys, 608 were used for analysis, as some surveys were considered incomplete. Convenience sampling was employed and the survey was self-administered.

\subsection{Measurements for Testing Hypotheses}

To analyze how the relationships among coffee shops' five sensory marketing factors, customer PAD emotions, flow, and behavioral intentions were influenced by usage motivations, this study employed frequency analysis, descriptive statistical analysis, reliability analysis, exploratory factor analysis of SPSS, confirmatory factor analysis, structural equation model analysis, and multi-group analysis of the AMOS program.

Coffee shops' five sensory marketing factors were measured based on the measurement index of Kotler (1973) and Zhao et al. (2019). The index contained three items each related to sight, smell, sound, taste, and touch [71,72]. Customers' PAD emotions were measured by adapting the measurement index of Mehrabian and Russell (1974) and Babin and Darden (1995). The index contained three items each related to dominance, pleasure, and arousal $[24,56]$. Flow was measured by editing and improving the measurement index of Trevino and Webster (1992). This index also contained three items [73]. Behavioral intention was measured by adapting the measurement index of Oliver (1993), Söderlund and Rosengren (2007), and Ryu et al. (2010); the index contained three items each related to re-visit intention and recommendation intention [74-76]. Here, behavioral intention was a second-order construct and re-visit intention and recommendation intention were first-order constructs. All the items were measured using a five-point Likert scale (ranging from $1=$ highly disagree to $5=$ highly agree). Usage motivations were categorized as hedonic or utilitarian, in accordance with the study by Oh et al. (2017) [25].

\section{Results}

Table 1 displays the demographic characteristics of the collected samples. A high proportion of respondents were in their twenties $(43.9 \%)$ and thirties $(34.2 \%)$, and there were more female respondents $(58.9 \%)$ than male. In terms of marital status, there were more single respondents (55.6\%) than married respondents. The most common respondent occupations were, in order, office jobs $(52.1 \%)$, homemakers $(13.5 \%)$, students $(12.7 \%)$, professional jobs $(12.5 \%)$, other $(5.4 \%)$, and self-employed (3.8\%). 
Table 1. Respondent characteristics $(\mathrm{N}=608)$.

\begin{tabular}{cccc}
\hline Characteristics & $\boldsymbol{n ( \% )}$ & Characteristics & $\boldsymbol{n} \mathbf{( \% )}$ \\
\hline Age & & Marital status & \\
$10 \mathrm{~s}$ & $16(2.6 \%)$ & Single & $338(55.6 \%)$ \\
$20 \mathrm{~s}$ & $267(43.9 \%)$ & Married & $270(44.4 \%)$ \\
$30 \mathrm{~s}$ & $208(34.2 \%)$ & Occupation & \\
$40 \mathrm{~s}$ & $91(15.0 \%)$ & Student & $77(12.7 \%)$ \\
$50 \mathrm{~s}$ & $20(3.3 \%)$ & Office job & $317(52.1 \%)$ \\
Over 60 & $6(1.0 \%)$ & Self-employed & $23(3.8 \%)$ \\
Gender & & Professional job & $76(12.5 \%)$ \\
Male & $250(41.1 \%)$ & Homemaker & $82(13.5 \%)$ \\
Female & $358(58.9 \%)$ & Other & $33(5.4 \%)$ \\
\hline
\end{tabular}

\subsection{Validity and Reliability of Measurements}

Confirmatory factor analysis (CFA) was conducted to verify the reliability and validity of the measured items. After analyzing a total of 33 items, three items per construct, GFI (goodness-of-fit index $)=0.909$, TLI $($ Tucker-Lewis index $)=0.956$, CFI $($ comparative fit index $)=0.963$, IFI (incremental fit index) $=0.963$; RMSEA (root mean square error of approximation) $=0.046$, all results that were consistent with standards [77].

The composite reliability of all construct items was 0.7 or above. Convergent validity was verified, as the average variance extracted (AVE) was also 0.5 or above [77]. There was no reliability problem, as the distribution of Cronbach's alpha ranged from 0.793 to 0.946 (see Table 2).

Table 2. Validity and reliability of measures.

\begin{tabular}{|c|c|c|c|c|c|}
\hline Construct & Standardized Loadings & $\mathrm{t}$-Value & $\mathrm{CCR}^{\mathrm{a}}$ & AVE $^{\mathbf{b}}$ & Cronbach's Alpha \\
\hline Sight & & & 0.807 & 0.582 & 0.944 \\
\hline The colors of the coffee shop are pleasing to the eye. & 0.791 & & & & \\
\hline The interior of the coffee shop is balanced. & 0.772 & $17.667^{* * *}$ & & & \\
\hline The interior decor of the coffee shop is appealing. & 0.724 & $16.774^{* * *}$ & & & \\
\hline Smell & & & 0.840 & 0.636 & 0.946 \\
\hline $\begin{array}{l}\text { The smell of the coffee shop fits the overall } \\
\text { atmosphere of the coffee shop. }\end{array}$ & 0.849 & & & & \\
\hline I like the smell of the coffee shop. & 0.781 & $20.404^{* * *}$ & & & \\
\hline The smell of the coffee shop soothes me. & 0.760 & $19.822^{* * *}$ & & & \\
\hline Sound & & & 0.865 & 0.681 & 0.864 \\
\hline I like the music in the coffee shop. & 0.847 & & & & \\
\hline $\begin{array}{c}\text { The music playing at the coffee shop gives me } \\
\text { pleasure. }\end{array}$ & 0.836 & $22.475^{* * *}$ & & & \\
\hline $\begin{array}{c}\text { The volume of music in the coffee shop is } \\
\text { appropriate. }\end{array}$ & 0.792 & $21.324^{* * *}$ & & & \\
\hline Taste & & & 0.948 & 0.859 & 0.804 \\
\hline The food and drinks are delicious. & 0.962 & & & & \\
\hline There are several types of food and drinks. & 0.878 & $37.728^{* * *}$ & & & \\
\hline The ingredients in the food and drinks are fresh. & 0.938 & $46.839^{* * *}$ & & & \\
\hline Touch & & & 0.949 & 0.862 & 0.835 \\
\hline The coffee shop is clean. & 0.955 & & & & \\
\hline $\begin{array}{c}\text { The heating or air conditioning in the coffee shop is } \\
\text { appropriate. }\end{array}$ & 0.912 & $41.745^{* * *}$ & & & \\
\hline The furniture in the coffee shop is comfortable. & 0.917 & $42.564^{* * *}$ & & & \\
\hline Pleasure & & & 0.913 & 0.778 & 0.793 \\
\hline I feel satisfied by my visit to the coffee shop. & 0.932 & & & & \\
\hline I feel happy when I visit the coffee shop. & 0.923 & $35.628^{* * *}$ & & & \\
\hline I feel pleasure when I visit the coffee shop. & 0.783 & $26.006^{* * *}$ & & & \\
\hline Arousal & & & 0.853 & 0.660 & 0.853 \\
\hline I feel energetic when I visit the coffee shop. & 0.837 & & & & \\
\hline I feel excited when I visit the coffee shop. & 0.802 & $20.977^{* * *}$ & & & \\
\hline I feel a sense of arousal when I visit the coffee shop. & 0.797 & $20.848^{* * *}$ & & & \\
\hline Dominance & & & 0.804 & 0.577 & 0.802 \\
\hline I feel confident in the coffee shop. & 0.726 & & & & \\
\hline I can act as I wish in the coffee shop. & 0.783 & $16.025^{* * *}$ & & & \\
\hline I am intimated by the atmosphere of the coffee shop. & 0.769 & $15.912^{* * *}$ & & & \\
\hline
\end{tabular}


Table 2. Cont.

\begin{tabular}{|c|c|c|c|c|c|}
\hline Construct & Standardized Loadings & t-Value & $\mathrm{CCR}^{\mathrm{a}}$ & $\mathrm{AVE}^{\mathrm{b}}$ & Cronbach's Alpha \\
\hline Flow & & & 0.949 & 0.860 & 0.945 \\
\hline $\begin{array}{l}\text { I forget about the outside world when I am in the } \\
\text { coffee shop. }\end{array}$ & 0.954 & & & & \\
\hline It feels as if time flies when I am in the coffee shop. & 0.885 & $38.009^{* * *}$ & & & \\
\hline $\begin{array}{l}\text { I feel oblivious to the flow of time when I am in the } \\
\text { coffee shop. } \\
\text { Behavioral Intention }\end{array}$ & 0.942 & $46.241^{* * *}$ & & & \\
\hline I will continue to visit the coffee shop. & 0.879 & & 0.884 & 0.718 & 0.881 \\
\hline I am inclined to visit the coffee shop repeatedly. & 0.770 & $22.490^{* * *}$ & & & \\
\hline I will revisit the coffee shop. & 0.888 & $26.936^{* * *}$ & & & \\
\hline $\begin{array}{l}\text { I will recommend the coffee shop to my } \\
\text { acquaintances. }\end{array}$ & 0.921 & & 0.927 & 0.809 & 0.925 \\
\hline $\begin{array}{l}\text { I will actively talk about the positive features of the } \\
\text { coffee shop to my acquaintances. }\end{array}$ & 0.841 & $30.093^{* * *}$ & & & \\
\hline $\begin{array}{l}\text { I will share the positive features of the coffee shop to } \\
\text { my acquaintances. }\end{array}$ & 0.933 & $37.456^{* * *}$ & & & \\
\hline
\end{tabular}

Notes: $\chi^{2} / d f=2.261, p<0.001$; goodness-of-fit $(\mathrm{GFI})=0.909$; Tucker-Lewis index $(\mathrm{TLI})=0.956$; comparative fit index $(\mathrm{CFI})=0.963$; incremental fit index $(\mathrm{IFI})=0.963$; root mean square error of approximation (RMSEA) $=0.046$; composite construct reliability ( $\left.{ }^{\mathrm{a}} \mathrm{CCR}\right)$; average variance extracted $\left({ }^{\mathrm{b}} \mathrm{AVE}\right) ;{ }^{* * *} p<0.001$.

The means, correlation coefficients, AVEs, and the square of the correlations of the 11 constructs used in this study are shown in Table 3 [77]. The results of the analysis confirmed the validity of the study's hypotheses, as all values of the AVE were greater than all values of the square of the correlations.

Table 3. Correlations and discriminant validity.

\begin{tabular}{|c|c|c|c|c|c|c|c|c|c|c|c|c|c|c|}
\hline & Construct & 1 & 2 & 3 & 4 & 5 & 6 & 7 & 8 & 9 & 10 & 11 & Mean & SD \\
\hline 1 & Sight & $0.58^{\mathrm{a}}$ & $0.41^{\mathrm{c}}$ & 0.18 & 0.17 & 0.20 & 0.10 & 0.07 & 0.05 & 0.02 & 0.11 & 0.03 & 3.55 & 0.64 \\
\hline 2 & Smell & $0.64^{b^{* *}}$ & 0.63 & 0.29 & 0.16 & 0.23 & 0.07 & 0.07 & 0.05 & 0.02 & 0.09 & 0.08 & 3.50 & 0.64 \\
\hline 3 & Sound & $0.42^{* *}$ & $0.54^{* *}$ & 0.68 & 0.08 & 0.16 & 0.04 & 0.07 & 0.08 & 0.02 & 0.08 & 0.07 & 3.33 & 0.65 \\
\hline 4 & Taste & $0.41^{* *}$ & $0.40^{* *}$ & $0.29^{* *}$ & 0.85 & 0.20 & 0.10 & 0.06 & 0.07 & 0.03 & 0.11 & 0.07 & 3.48 & 0.64 \\
\hline 5 & Touch & $0.44^{* *}$ & $0.48^{* *}$ & $0.40^{* *}$ & $0.44^{* *}$ & 0.86 & 0.10 & 0.09 & 0.04 & 0.04 & 0.08 & 0.04 & 3.62 & 0.65 \\
\hline 6 & Dominance & $0.31^{* *}$ & $0.28^{* *}$ & $0.22^{* *}$ & $0.31^{* *}$ & $0.31^{* *}$ & 0.57 & 0.16 & 0.06 & 0.01 & 0.18 & 0.05 & 3.67 & 0.57 \\
\hline 7 & Pleasure & $0.28^{* *}$ & $0.28^{* *}$ & $0.27^{* *}$ & $0.26^{* *}$ & $0.31^{* *}$ & $0.40^{* *}$ & 0.77 & 0.22 & 0.17 & 0.10 & 0.30 & 3.83 & 0.52 \\
\hline 8 & Arousal & $0.24^{* *}$ & $0.24^{* *}$ & $0.29^{* *}$ & $0.27^{* *}$ & $0.20^{* *}$ & $0.25^{* *}$ & $0.47^{* *}$ & 0.66 & 0.07 & 0.17 & 0.10 & 3.11 & 0.74 \\
\hline 9 & Flow & $0.16^{* *}$ & $0.16^{* *}$ & $0.17^{* *}$ & $0.18^{* *}$ & $0.22^{* *}$ & $0.13^{* *}$ & $0.41^{* *}$ & $0.27^{* *}$ & 0.86 & 0.08 & 0.13 & 3.26 & 0.78 \\
\hline 10 & Re-visit & $0.34^{* *}$ & $0.31^{* *}$ & $0.28^{* *}$ & $0.33^{* *}$ & $0.29^{* *}$ & $0.42^{* *}$ & $0.32^{* *}$ & $0.42^{* *}$ & $0.29^{* *}$ & 0.71 & 0.23 & 4.06 & 0.60 \\
\hline 11 & Recommen-dation & $0.18^{* *}$ & $0.29^{* *}$ & $0.26^{* *}$ & $0.27^{* *}$ & $0.20^{* *}$ & $0.24^{* *}$ & $0.55^{* *}$ & $0.38^{* *}$ & $0.37^{* *}$ & $0.48^{* *}$ & 0.80 & 3.34 & 0.83 \\
\hline
\end{tabular}

\subsection{Hypotheses Testing}

This study used a structural equation model analysis (SEM) to verify its hypotheses. The results showed that there is satisfactory model fit, with $\chi^{2} / d f=2.329, p<0.001$; GFI $=0.901$; TLI $=0.953$; $\mathrm{CFI}=0.959 ; \mathrm{RMSEA}=0.047$. Figure 2 shows the standardized coefficients and denotes the verification of the hypotheses.

It was shown that "sight" had a positive effect on dominance $(\beta=0.145, p<0.05)$, but had insignificant effect on pleasure and arousal. Thus, Hypothesis 1 was only partially verified. As "smell" did not have significant effects on any of the three PAD emotions, Hypothesis 2 was not supported. "Sound" had a positive effect on arousal $(\beta=0.164, p<0.01)$ but did not have significant effects on pleasure and dominance. Thus, Hypothesis 3 was partially verified. As "taste" had positive effects on dominance $(\beta=0.164, p<0.01)$ and arousal $(\beta=0.106, p<0.05)$, it did not have a significant effect on pleasure. Hence, Hypothesis 4 was also partially verified. As "touch" had positive effects on dominance $(\beta=0.159, p<0.01)$ and pleasure $(\beta=0.113, p<0.05)$, it did not have significant effects on arousal. Hypothesis 5 was partially verified. 


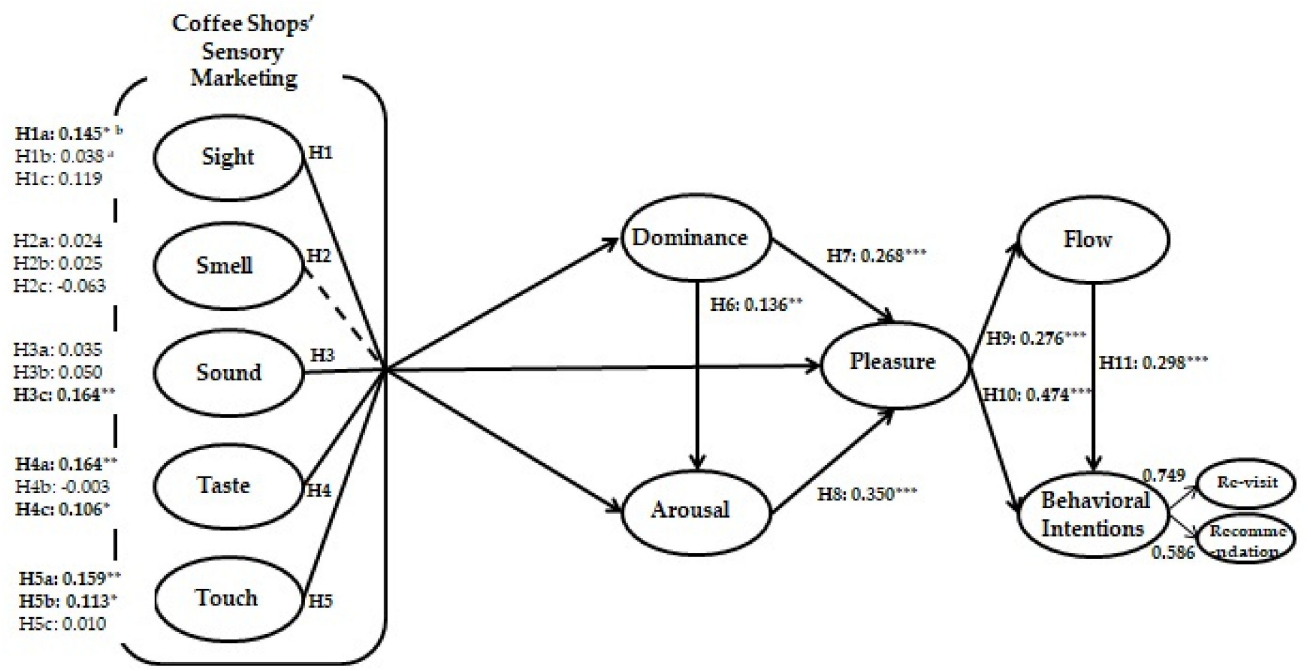

Figure 2. Structural equation model with parameter estimates. Notes: ${ }^{a}$ Standardized estimates; b *** $p<0.001,{ }^{* *} p<0.01,{ }^{*} p<0.05 ; \chi^{2} / d f=2.329(p<0.001)$; GFI = 0.901; TLI = 0.953; CFI =0.959; RMSEA $=0.047 ; \longrightarrow$ significant effect; $\cdots . . . . . . . . . .>$ non-significant effect.

Dominance had a positive effect on arousal $(\beta=0.136, p<0.01)$; dominance had a positive effect on pleasure $(\beta=0.268, p<0.001)$; arousal had a positive effect on pleasure $(\beta=0.350, p<0.001)$. Thus, Hypotheses 6, 7 and 8 were verified.

Pleasure had a positive effect on flow $(\beta=0.276, p<0.001)$; pleasure had a positive effect on behavioral intentions $(\beta=0.474, p<0.001)$. Therefore, Hypotheses 9 and 10 were verified. Finally, flow had a positive effect on behavioral intentions $(\beta=0.298, p<0.001)$, hypothesis 11 was also verified.

The results of the moderating effects of usage motivations are shown in Table 4 . The multi-group analysis revealed significant moderating effects on the relationships between the sensory marketing factor of "touch" and pleasure and also between pleasure and flow, both according to the hedonic usage motivation (drinking coffee, hanging out, and taking a break) and the utilitarian usage motivation (studying, meetings, and taking care of business). Although "touch" did not have a significant effect on pleasure $(\beta=0.015, \mathrm{p}>0.05)$ with hedonic usage motivation, the effect was significant with utilitarian usage motivation $(\beta=0.289, p<0.001)$. In addition, it was shown that pleasure had a positive effect on flow for both hedonic and utilitarian motivations, the comparison of the standardized coefficients showed that utilitarian usage motivation $(\beta=0.432, p<0.001)$ had a significantly greater moderating effect on the relationship between pleasure and flow pleasure compared to hedonic usage motivation $(\beta=0.192, p<0.001)$. Therefore, Hypothesis 12 was partially verified. 
Table 4. Moderating effects of usage motivations.

\begin{tabular}{|c|c|c|c|c|c|c|c|c|c|}
\hline & \multirow[t]{2}{*}{ Structural Relationship } & \multicolumn{2}{|c|}{ Hedonic $(\mathrm{N}=415)$} & \multicolumn{2}{|c|}{$\begin{array}{l}\text { Utilitarian } \\
(\mathrm{N}=193)\end{array}$} & \multirow{2}{*}{\multicolumn{2}{|c|}{$\begin{array}{c}\text { Free Constraine } \\
\chi^{2}(\mathrm{df}=916) \chi^{2}(\mathrm{df}=917)\end{array}$}} & \multirow[t]{2}{*}{$\Delta x^{2}$} & \multirow[t]{2}{*}{ Results } \\
\hline & & $\beta$ & t-value & $\beta$ & t-value & & & & \\
\hline H1a & Sight $\rightarrow$ Dominance & 0.223 & $2.451^{*}$ & 0.044 & 0.388 & 1694.402 & 1696.225 & 1.823 & Rejected \\
\hline $\mathrm{H} 1 \mathrm{~b}$ & Sight $\rightarrow$ Pleasure & -0.028 & -0.364 & 0.072 & 0.782 & 1694.402 & 1695.068 & 0.666 & Rejected \\
\hline $\mathrm{H} 1 \mathrm{c}$ & Sight $\rightarrow$ Arousal & 0.106 & 1.235 & 0.094 & 0.973 & 1694.402 & 1694.413 & 0.011 & Rejected \\
\hline $\mathrm{H} 2 \mathrm{a}$ & Smell $\rightarrow$ Dominance & 0.071 & 0.767 & -0.077 & -0.593 & 1694.402 & 1695.245 & 0.843 & Rejected \\
\hline $\mathrm{H} 2 \mathrm{~b}$ & Smell $\rightarrow$ Pleasure & 0.065 & 0.830 & -0.032 & -0.294 & 1694.402 & 1694.943 & 0.541 & Rejected \\
\hline $\mathrm{H} 2 \mathrm{c}$ & Smell $\rightarrow$ Arousal & 0.020 & 0.230 & -0.243 & $-2.168^{*}$ & 1694.402 & 1697.450 & 3.048 & Rejected \\
\hline $\mathrm{H} 3 \mathrm{a}$ & Sound $\rightarrow$ Dominance & 0.026 & 0.384 & 0.029 & 0.278 & 1694.402 & 1694.402 & 0 & Rejected \\
\hline $\mathrm{H} 3 \mathrm{~b}$ & Sound $\rightarrow$ Pleasure & 0.068 & 1.153 & 0.023 & 0.261 & 1694.402 & 1694.595 & 0.193 & Rejected \\
\hline $\mathrm{H} 3 \mathrm{c}$ & Sound $\rightarrow$ Arousal & 0.146 & $2.248^{*}$ & 0.277 & $3.008^{* *}$ & 1694.402 & 1695.796 & 1.394 & Rejected \\
\hline $\mathrm{H} 4 \mathrm{a}$ & Taste $\rightarrow$ Dominance & 0.111 & 1.761 & 0.205 & $2.263^{*}$ & 1694.402 & 1695.176 & 0.774 & Rejected \\
\hline $\mathrm{H} 4 \mathrm{~b}$ & Taste $\rightarrow$ Pleasure & 0.053 & 0.980 & -0.069 & -0.924 & 1694.402 & 1696.090 & 1.688 & Rejected \\
\hline $\mathrm{H} 4 \mathrm{c}$ & Taste $\rightarrow$ Arousal & 0.130 & $2.175^{*}$ & 0.117 & 1.498 & 1694.402 & 1694.404 & 0.002 & Rejected \\
\hline H5a & Touch $\rightarrow$ Dominance & 0.154 & $2.463^{*}$ & 0.229 & $2.196^{*}$ & 1694.402 & 1694.730 & 0.328 & Rejected \\
\hline $\mathrm{H} 5 \mathrm{~b}$ & Touch $\rightarrow$ Pleasure & 0.015 & 0.278 & 0.289 & $3.348^{* * *}$ & 1694.402 & 1701.987 & 7.585 & Supported \\
\hline $\mathrm{H} 5 \mathrm{c}$ & Touch $\rightarrow$ Arousal & -0.025 & -0.425 & 0.174 & 1.922 & 1694.402 & 1697.852 & 3.45 & Rejected \\
\hline $\mathrm{H} 6$ & Dominance $\rightarrow$ Arousal & 0.165 & $2.611^{* *}$ & 0.012 & 0.151 & 1694.402 & 1696.370 & 1.968 & Rejected \\
\hline $\mathrm{H} 7$ & Dominance $\rightarrow$ Pleasure & 0.329 & $5.476^{* * *}$ & 0.182 & $2.473^{*}$ & 1694.402 & 1696.244 & 1.842 & Rejected \\
\hline $\mathrm{H} 8$ & Arousal $\rightarrow$ Pleasure & 0.310 & $5.722^{* * *}$ & 0.396 & $5.412^{* * *}$ & 1694.402 & 1695.006 & 0.604 & Rejected \\
\hline H9 & Pleasure $\rightarrow$ Flow & 0.192 & $3.730^{* * *}$ & 0.431 & $6.124^{* * *}$ & 1694.402 & 1701.560 & 7.158 & Supported \\
\hline H10 & Pleasure $\rightarrow$ Behavioral Intention & 0.480 & $7.108^{* * *}$ & 0.473 & $5.004^{* * *}$ & 1694.402 & 1694.707 & 0.305 & Rejected \\
\hline H11 & Flow $\rightarrow$ Behavioral Intention & 0.321 & $5.090^{* * *}$ & 0.266 & $3.011^{* *}$ & 1694.402 & 1694.403 & 0.001 & Rejected \\
\hline
\end{tabular}

\section{Discussion and Conclusions}

Many scholars have paid much attention to identifying effective and efficient marketing strategies to improve customers' behavioral intentions because consumers' satisfaction and positive behavioral intentions can be critical resources in achieving business sustainability [78,79]. Accordingly, researchers began to focus on sensory marketing because the five sensory factors are considered the basic components in the formation of customers' shopping-related feelings and experiences, which further determine their future consumption behaviors $[15,17]$. This present study verified whether coffee shops' sensory marketing factors could possibly enhance customers' behavioral intentions through more positive emotions. The findings of this study indicate that although the coffee shop industry is currently facing a saturated market situation, effective sensory marketing could be used as a strategy to attract more customers. For the sustainability of the coffee shop industry, customers' positive intentions to revisit and recommend coffee shops could be the most important factor. Based on the present findings, this study provides several important theoretical and practical implications to support future studies in examining more effective sensory marketing strategies to make the coffee shop industry sustainable. These implications are as follows.

\subsection{Theoretical Implications}

This study investigated the relationships among coffee shops' five sensory marketing factors, the PAD emotions of customers, flow, and behavioral intentions to assist in ensuring sustainability of the coffee shop market in Korea. The moderating effects of usage motivations were also analyzed. The results suggest the following theoretical implications.

First, this study identified the relative importance of the five sensory factors in coffee shop marketing. "Taste," "sight," and "touch" had significant effects on customers' emotions, dominance, and only "touch" had a significant effect on pleasure, and "sound" and "taste" had significant effects 
on arousal. "Smell" did not have a significant effect on any of the PAD emotions. Although the importance and effects of each of the senses may vary depending on the location or industry, this study provided a new theoretical base related to the five sensory factors that coffee shops should emphasize in sensory marketing.

Second, prior studies regarding the impact of customer emotions on the food service industry focused only on pleasure and not on the other two PAD emotions, or they focused only on positive or negative emotions in general. However, this study focused more intensely on the recent increase in the number of consumers who visit coffee shops to study or take care of business. Therefore, this study considered the three PAD emotions as well as flow, something that had been rarely studied in the context of coffee shop consumers. This approach can provide a new theoretical basis for related future studies by analyzing the relationship between the emotions of customers in modern society and flow.

Third, this study, by verifying the relationships among the PAD emotions, provided a new model that focuses on the theory that the complex emotions of humans are not independent, but can only be understood through their relationships. While the existing literature has analyzed only one or two types of consumer emotions (pleasure or pleasure and arousal), this study examined the complete range of the PAD emotions, including dominance. The results confirmed the importance of dominance in sensory marketing: feelings of dominance by coffee shop customers had positive effects on pleasure and arousal. This study's new suggested approach is expected to be useful for future in-depth investigations for relevant issues.

Lastly, this study identified significant differences in the verified relationships among sensory factors according to usage motivation types (hedonic vs. utilitarian usage). Although the relationship between the sensory marketing factor of "touch" and pleasure was not significant for the hedonic usage motivation, it was shown that touch was significantly more positive and led to an increase in pleasure among study respondents with the utilitarian usage motivation. Significant effects of pleasure and flow were observed in respondents with both hedonic and utilitarian usage motivation; respondents with utilitarian usage motivation had a stronger connection to flow from pleasure than those with hedonic usage motivation. These results are in line with the prior literature that suggests significant differences in consumption behavior and future behavioral intention based on usage motivations. This study verified significant differences in customers' experiential factors related to the senses, emotions, and flow depending on their usage motivations. Based on the study' findings, a fundamental and more complete basis of knowledge about sensory marketing for related studies in the future has been provided.

\subsection{Practical Implications}

This study was designed to examine effective sensory marketing strategies for the coffee shop industry. Based on the findings, practical implications that can help establish strategies for sustainable growth in the saturated coffee shop industry are provided.

Music as a sensory marketing factor of "sound" played in coffee shops was shown to increase the emotion of arousal, filling customers with energy and spirit. Although it is known that coffee shops play music according to the season, the results of this study demonstrated the need for professional selection of music that considers the brand concept, recent trends, season, weather, and the time period. For example, Starbucks acquired a record label company in 1999 in order to provide music streaming services; the company's U.S. headquarters produces CDs of songs that are selected according to the season and the time period and distributes them to Starbucks outlets all over the world [80]. There has been an increase in the number of loyal fans who listen to Starbucks music in their own offices or homes as a result of this professional music selection.

Based on evidence that the sensory marketing factor of "taste" increases feelings of dominance and pleasure in customers, efforts should be made to develop various food and drink options, maintain the freshness of ingredients, and ensure that food and drinks are delicious. As coffee shops are part of the food service industry, the taste factor cannot be overlooked; there should be concerted 
efforts to accommodate rapidly changing consumer preferences. Implementing policies that provide performance-related pay or creating education programs or evaluation measures to improve the techniques or skills of baristas and chefs may provide a positive stimulus for coffee shops.

Similarly, based on the result that the sensory marketing factor of "sight" positively affects customers' feelings of dominance, coffee shop managers should focus on creating interior decor that promotes a harmonious atmosphere within the shop space. The interior atmosphere should match the brand concept, and coffee shops should strive to become a multi-purpose resting area. As today's consumers are extremely sensitive to new trends and are influenced by sensory factors, coffee shop managers should endeavor to provide a new and comfortable atmosphere by focusing on freshening up or renovating the coffee shop space seasonally or at regular intervals.

There should always be an appropriate degree of heating or air conditioning in a coffee shop, based on evidence that "touch" as a sensory marketing factor positively affects the feelings of dominance and pleasure. As there are an increasing number of consumers who experience physical effects and discomfort due to the murky air from fine dust, coffee shop managers should equip coffee shops with air-purification systems. Providing comfortable furniture and tableware will also appeal to customers' sense of touch.

This study verified the relationships among the PAD emotions. The feeling of dominance that can be achieved through a sense of "my own place," "my table," and "my space," despite a coffee shop's small size, can positively affect feelings of arousal and pleasure; the results of this study demonstrate the importance of the feeling of dominance, in particular. Therefore, coffee shop managers should provide individual seats, increasing the number of tables or seats for solo customers, so that customers feel a sense of dominance within their private spaces; expand the space between tables or seats; and/or reshuffle seating configurations in order to satisfy as many of the various customer preferences as possible.

It was shown that coffee shop customers experience flow through a feeling of pleasure. They create pleasure via various sensory stimuli experienced while visiting coffee shops, such as interior decor, music, delicious food and drinks, cool and comfortable atmosphere, and comfortable furniture. These feelings ultimately lead to flow, which makes customers feel indifferent about passing time. As flow leads to positive behavioral intentions, coffee shop managers should continuously develop new and varied sustainable sensory stimuli so that customers can always feel pleasure when visiting coffee shops.

Finally, a moderating effect was observed according to whether usage motivations were hedonic or utilitarian. In regard to the relationship between "touch" and pleasure, although there was no statistically significant relationship with the hedonic usage motivation, "touch" had a positive effect on pleasure for study participants with the utilitarian usage motivation. This result suggests that coffee shop customers with the utilitarian usage motivation react more sensitively to the sensory marketing factor of "touch." Coffee shop managers should concentrate on providing pleasant and comfortable seating configurations to customers with a high level of utilitarian motivations (i.e., taking care of business, studying, or having meetings). This study found another significant moderating effect on the relationship between pleasure and flow. Although it was shown that pleasure increases flow for both types of usage motivation, it had a slightly stronger effect on flow for coffee shop consumers with utilitarian usage motivations. Therefore, developing sensory stimulating factors so that all customers feel pleasure visiting coffee shops is key, as customer pleasure can increase behavioral intentions.

\section{Limitations and Future Research}

This study has various academic and practical implications. However, there are limitations to the study, and some underexplored areas remain for future research.

First, this study was based on customers of six coffee shop franchises in Korea. For more reliable and generalized results, an analysis of data from customers from a wider variety of coffee shop franchises and from different regions is needed. 
Second, this study was based on an online survey completed by people living in Korea aged 20 and older. They were asked to respond to the survey based on their memories of coffee shop experiences over the past three months. These surveys relying on memory are useful, as coffee shops are locations people visit frequently, even on a daily basis. However, it may be a limitation of this study that the on-site interview survey was not conducted and completed within coffee shops. Future studies should address this concern.

Lastly, sensory marketing, which stimulates the human senses, is related to everyday activities and connects to all consumption activities. However, this study limited its scope to coffee shops. As there will be different results from sensory stimulus and different marketing implications depending on the field or subject of the study, future studies should expand the research on sensory marketing by applying more various strategies across different industries or fields.

Author Contributions: All authors contributed equally to this work.

Conflicts of Interest: The authors declare no conflict of interest.

\section{References}

1. Purnomo, M. Contesting Indonesia's Single Origin Coffee Market: A Dynamic Capabilities Perspective. Asian Soc. Sci. 2018, 14, 91-101. [CrossRef]

2. Ahn, S.Y. Coffee Shops Going Out of Business. Available online: http://biz.chosun.com/site/data/html_dir/ 2019/09/17/2019091700430.html (accessed on 17 September 2019).

3. Hooker, L. Is the UK Reaching Coffee Shop Saturation Point? Available online: https://www.bbc.com/news/ business-41251451 (accessed on 14 September 2017).

4. Jargon, J. Too Much Caffeine? Coffee Shops Face a Shakeout. Available online: https:/www.wsj.com/articles/ american-retail-has-a-coffee-problem-1510056002 (accessed on 18 December 2017).

5. Lee, T.-S. Korea's Coffee Imports Fall in 2018 for 1st Time in 6 Years. Available online: http://www.koreaherald. com/view.php?ud=20190217000033\&ACE_SEARCH=1 (accessed on 17 February 2019).

6. de Jonge, J.; Peeters, M. The vital worker: Towards sustainable performance at work. Int. J. Environ. Res. Public Health 2019, 16, 910. [CrossRef] [PubMed]

7. Chams, N.; García-Blandón, J. On the importance of sustainable human resource management for the adoption of sustainable development goals. Res. Conserv. Recycl. 2019, 141, 109-122. [CrossRef]

8. Starbucks Global Responsibility Report. Global Social Impact 2017. Available online: https://globalassets. starbucks.com/assets/8c1f8c07efde407e9d48bfaf518c0b45.pdf (accessed on 1 October 2017).

9. Chiang, W.Y. Applying data mining for online CRM marketing strategy: An empirical case of coffee shop industry in Taiwan. Br. Food J. 2018, 120, 665-675. [CrossRef]

10. Rahmah, K.; Sumarwan, U.; Najib, M. The Effect of Brand Equity, Marketing Mix, And Lifestyle To Purchase Decision At Maxx Coffee, Bogor. J. Consum. Sci. 2018, 3, 1-15. [CrossRef]

11. Kim, S.H.; Kim, M.; Holland, S. How customer personality traits influence brand loyalty in the coffee shop industry: The moderating role of business types. Int. J. Hosp. Tour. Adm. 2018, 19, 311-335. [CrossRef]

12. Li, Y.; Liu, B.; Huan, T.C.T. Renewal or not? Consumer response to a renewed corporate social responsibility strategy: Evidence from the coffee shop industry. Tour. Manag. 2019, 72, 170-179. [CrossRef]

13. Kuczamer-Kłopotowska, S. Sensory marketing as a new tool of supporting the marketing communication process in tourism services sector. Handel Wewnętrzny 2017, 367, 226-235.

14. Kim, C.H.; Jung, Y.S. A Study on the Effects of Experiential Marketing on Satisfaction, Loyalty and Purchase Intention. Korean J. Bus. Adm. 2018, 31, 603-624.

15. Hultén, B. Sensory Marketing: Theoretical and Empirical Grounds; Routledge: London, UK, 2015.

16. Krishna, A. An integrative review of sensory marketing: Engaging the senses to affect perception, judgment and behavior. J. Consum. Psychol. 2012, 22, 332-351. [CrossRef]

17. Krishna, A.; Cian, L.; Aydınoğlu, N.Z. Sensory aspects of package design. J. Retail. 2017, 93, 43-54. [CrossRef]

18. Wade Clarke, D.; Perry, P.; Denson, H. The sensory retail environment of small fashion boutiques. J. Fash. Market. Manag. Int. J. 2012, 16, 492-510. [CrossRef] 
19. Doucé, L.; Janssens, W. The presence of a pleasant ambient scent in a fashion store: The moderating role of shopping motivation and affect intensity. Environ. Behav. 2013, 45, 215-238. [CrossRef]

20. Hinestroza, N.B.; James, P. The effects of sensory marketing on the implementation of fast-food marketing campaigns. J. Manag. Market. Res. 2014, 14, 1-11.

21. Hussain, S. The impact of sensory branding (five senses) on consumer: A case study on KFC (Kentucky Fried Chicken). Int. J. Res. Bus. Manag. 2014, 2, 2347-4572.

22. Anvar, M. The Effect of Multi-Sensory Branding on Purchase Intention at Coffee Shops in South Africa. Master's Thesis, Witwatersrand University, Johannesburg, South Africa, March 2016.

23. Pierce, J.L.; Brown, G. Psychological ownership and the physical environment in organizations. Org. Behav. Phys. Environ. 2019, 1, 67-95.

24. Mehrabian, A.; Russell, J.A. An Approach to Environmental Psychology; The MIT Press: Cambridge, MA, USA, 1974.

25. Oh, S.K.; Yoon, H.S.; Yoon, H.H. Effect of Emotional-Utilitarian Motivation on Coffee Shop Selection Attribution. J. Korean Soc. Food Cult. 2017, 32, 111-117.

26. Schmitt, B. Experiential marketing. J. Market. Manag. 1999, 15, 53-67. [CrossRef]

27. Erdil, T.S. Effects of customer brand perceptions on store image and purchase intention: An application in apparel clothing. Procedia Soc. Behav. Sci. 2015, 207, 196-205. [CrossRef]

28. Lindstrom, M. Brand Sense: How to Build Powerful Brands Through Touch, Taste, Smell, Sight and Sound; Strategic Direction: Bingley, UK, 2006; p. 22.

29. Ebster, C. Store Design and Visual Merchandising: Creating Store Space That Encourages Buying; Business Expert Press: New York, NY, USA, 2011.

30. Lindstrom, M. Broad sensory branding. J. Prod. Brand Manag. 2005, 14, 84-87. [CrossRef]

31. Herz, R.S.; Engen, T. Odor memory: Review and analysis. Psychon. Bull. Rev. 1996, 3, 300-313. [CrossRef] [PubMed]

32. Hultén, B.; Broweus, N.; Van Dijk, M. What Is Sensory Marketing? In Sensory Marketing; Palgrave Macmillan: London, UK, 2009; pp. 1-23.

33. Ikeda, K. New seasonings. Chem. Senses 2002, 27, 847-849. [CrossRef] [PubMed]

34. Helmefalk, M.; Hultén, B. Multi-sensory congruent cues in designing retail store atmosphere: Effects on shoppers' emotions and purchase behavior. J. Retail. Consum. Serv. 2017, 38, 1-11. [CrossRef]

35. Iqbal, J. Employing sensory marketing as a promotional advantage for creating brand differentiation and brand loyalty. Pak. J. Comm. Soc. Sci. 2016, 10, 725-734.

36. Randhir, R.; Latasha, K.; Tooraiven, P.; Monishan, B. Analyzing the impact of sensory marketing on consumers: A case study of KFC. J. US-China Public Adm. 2016, 13, 278-292.

37. Moreira, A.C.; Fortes, N.; Santiago, R. Influence of sensory stimuli on brand experience, brand equity and purchase intention. J. Bus. Econ. Manag. 2017, 18, 68-83. [CrossRef]

38. Hultén, B. Sensory marketing: The multi-sensory brand-experience concept. Eur. Bus. Rev. 2011, 23, $256-273$. [CrossRef]

39. Rodrigues, C.; Hultén, B.; Brito, C. Sensorial strategies for value co-creation. Innov. Market. 2011, 7, 47-54.

40. Havlena, W.J.; Holbrook, M.B. The varieties of consumption experience: Comparing two typologies of emotion in consumer behavior. J. Consum. Res. 1986, 13, 394-404. [CrossRef]

41. Miller, S. Ends, Means, and Galumphing: Some Leitmotifs of Play 1. Am. Anthropol. 1973, 75, 87-98. [CrossRef]

42. Csikszentmihalyi, M.; Csikszentmihalyi, I. Beyond Boredom and Anxiety; Jossey-Bass: San Francisco, CA, USA, 1975; Volume 721.

43. Gao, L.; Bai, X. Online consumer behaviour and its relationship to website atmospheric induced flow: Insights into online travel agencies in China. J. Retail. Consum. Serv. 2014, 21, 653-665. [CrossRef]

44. Reid, D. A model of playfulness and flow in virtual reality interactions. Presence Teleoper. Vir. Environ. 2004, 13, 451-462. [CrossRef]

45. Mun, Y.J.; Lee, J.H. A Study on the Performance of Online Community Reputation, Social Presence, Interactivity, Playfulness: Mediating Role of Trust and Flow. Glob. E Bus. Assoc. 2008, 9, 75-99.

46. Hoffman, D.L.; Novak, T.P. Marketing in hypermedia computer-mediated environments: Conceptual foundations. J. Mark. 1996, 60, 50-68. [CrossRef] 
47. Koufaris, M. Applying the technology acceptance model and flow theory to online consumer behavior. Inform. Syst. Res. 2002, 13, 205-223. [CrossRef]

48. Ko, J.M.; Shin, J.Y.; Ko, E.J.; Chae, H.J. The Effects of Image Contents Based Fashion Brands' SNS Toward Flow and Brand Attitude: Focus on Pleasure Emotion as Mediator. Fash. Text. Res. J. 2014, 16, 908. [CrossRef]

49. Brengman, M. The Impact of Colour in the Store Environment: An Environmental Psychology Approach. Ph.D. Thesis, Ghent University, Ghent, Belgium, August 2002.

50. Ryu, K.; Jang, S.S. The effect of environmental perceptions on behavioral intentions through emotions: The case of upscale restaurants. J. Hosp. Tour. Res. 2007, 31, 56-72. [CrossRef]

51. Krishna, A.; Morrin, M.; Sayin, E. Smellizing cookies and salivating: A focus on olfactory imagery. J. Consum. Res. 2013, 41, 18-34. [CrossRef]

52. Jung, J.Y. A Study on the Effects of the Food Space of Hotel Restaurants on Behavioral Intention. Master's Thesis, Kyonggi University, Seoul, Korea, August 2015.

53. Kang, T.H.; Kim, B.S. The Effect of Physical Environment in Japanese Restaurant on Emotional Reaction and Customer Loyalty. J. Hotel Resort 2016, 15, 421-439.

54. Im, S.S. The Effect of Physical Environment of Dessert Cafe on the Emotional Responses and Purchasing Intentions. J. Tour. Leis. Res. 2017, 29, 275-294.

55. Kim, J.; Noh, J. Effects of Casino Servicescape and Customer Interaction on Chinese and Japanese Customers' Emotions and Loyalty. J. Serv. Res. Stud. 2018, 8, 1-24.

56. Babin, B.J.; Darden, W.R. Consumer self-regulation in a retail environment. J. Retail. 1995, 71, 47-70. [CrossRef]

57. Ward, J.C.; Barnes, J.W. Control and affect: The influence of feeling in control of the retail environment on affect, involvement, attitude, and behavior. J. Bus. Res. 2001, 54, 139. [CrossRef]

58. Kuppens, P. Individual differences in the relationship between pleasure and arousal. J. Res. Pers. 2008, 42, 1053-1059. [CrossRef]

59. Hanzaee, K.H.; Khanzadeh, M. Investigation of the effect of consumption emotions on satisfaction and word of mouth communications. Middle East J. Sci. Res. 2011, 9, 566-571.

60. Clarke, S.G.; Haworth, J.T. 'Flow' experience in the daily lives of sixth-form college students. Br. J. Psychol. 1994, 85, 511-523. [CrossRef]

61. Csikszentmihalyi, M. Play and intrinsic rewards. In Flow and the Foundations of Positive Psychology; Springer: Dordrecht, The Netherlands, 2014.

62. Kulviwat, S.; Zhang, Y.; Fan, J.; Zheng, L. Understanding consumer shopping behaviour: A comparison of three theories of emotions in predicting online flow. Int. J. Electr. Mark. Retail. 2016, 7, 3-21. [CrossRef]

63. Ryu, K.; Jang, S. DINESCAPE: A scale for customers' perception of dining environments. J. Foodserv. Bus. Res. 2008, 11, 2-22. [CrossRef]

64. Tantanatewin, W.; Inkarojrit, V. The influence of emotional response to interior color on restaurant entry decision. Int. J. Hosp. Manag. 2018, 69, 124-131. [CrossRef]

65. Ali, F. Hotel website quality, perceived flow, customer satisfaction and purchase intention. J. Hosp. Tour. Technol. 2016, 7, 213-228. [CrossRef]

66. Liu, H.; Chu, H.; Huang, Q.; Chen, X. Enhancing the flow experience of consumers in China through interpersonal interaction in social commerce. Comput. Hum. Behav. 2016, 58, 306-314. [CrossRef]

67. Lunardo, R.; Mbengue, A. Perceived control and shopping behavior: The moderating role of the level of utilitarian motivational orientation. J. Retail. Consum. Serv. 2009, 16, 434-441. [CrossRef]

68. Jin, N.; Lee, S.; Huffman, L. Impact of restaurant experience on brand image and customer loyalty: Moderating role of dining motivation. J. Travel Tour. Mark. 2012, 29, 532-551. [CrossRef]

69. Margarita Orozco-Gómez, M.; Rialp, J.; González, E. Impact of the Attractiveness of a Shopping Center in the Consumer Satisfaction: The Moderator Role of the Motivations and the Frequency of Visits; ACR Latin American Advances: Duluth, MN, USA, 2017.

70. Hyun, S.S.; Kang, J. A better investment in luxury restaurants: Environmental or non-environmental cues? Int. J. Hosp. Manag. 2014, 39, 57-70. [CrossRef]

71. Kotler, P. Atmospherics as a marketing tool. J. Retail. 1973, 49, 48-64.

72. Zhao, J.B.; Wang, Y.L.; Ma, Q.W.; Zhao, J.B.; Zhang, X.Y.; Zou, L.Q. The Chemosensory Pleasure Scale: A New Assessment for Measuring Hedonic Smell and Taste Capacities. Chem. Senses 2019, 44, 457-464. [CrossRef] 
73. Trevino, L.K.; Webster, J. Flow in computer-mediated communication: Electronic mail and voice mail evaluation and impacts. Commun. Res. 1992, 19, 539-573. [CrossRef]

74. Oliver, R.L. Cognitive, affective, and attribute bases of the satisfaction response. J. Consum. Res. 1993, 20, 418-430. [CrossRef]

75. Söderlund, M.; Rosengren, S. Receiving word-of-mouth from the service customer: An emotion-based effectiveness assessment. J. Retail. Consum. Serv. 2007, 14, 123-136. [CrossRef]

76. Ryu, K.; Han, H.; Jang, S. Relationships among hedonic and utilitarian values, satisfaction and behavioral intentions in the fast-casual restaurant industry. Int. J. Contemp. Hosp. Manag. 2010, 22, 416-432. [CrossRef]

77. Hair, J.F.; Black, W.C.; Babin, B.J.; Anderson, R.E. Multivariate Data Analysis; Pearson Education Limited: London, UK, 2014.

78. Gębarowski, M.; Cholewa-Wójcik, A. Popularization of an ecological dimension of sustainable consumption using sensory marketing. J. Agrobus. Rural Dev. 2015, 3, 379-385. [CrossRef]

79. Terlau, W.; Hirsch, D. Sustainable consumption and the attitude-behaviour-gap phenomenon-causes and measurements towards a sustainable development. Int. J. Food Syst. Dyn. 2015, 6, 159-174.

80. Lee, J.E. Starbucks Management-The Secret of Loud 'Places' That Are Helpful for Studying. Available online: http://biz.chosun.com/site/data/html_dir/2019/01/02/2019010202232.html (accessed on 3 January 2019).

(C) 2019 by the authors. Licensee MDPI, Basel, Switzerland. This article is an open access article distributed under the terms and conditions of the Creative Commons Attribution (CC BY) license (http://creativecommons.org/licenses/by/4.0/). 